\title{
IMPLEMENTASI PENYELESAIAN WANPRESTASI DALAM PERJANJIAN KREDIT PERBANKAN PADA MASA PANDEMI COVID-19 DI BPR INSUMO SUMBERARTO KEDIRI
}

\author{
Nurbaedah \\ Program Studi Magister Ilmu Hukum, Universitas Islam Kadiri, Kediri, Jawa Timur. \\ Correspondent email : nurbaedah@uniska-kediri.ac.id
}

$\begin{array}{lll}\mid \text { Article History } & : & \\ \mid \text { | Submission } & : & \text { 23 Oktober 2021 } \\ \text { | Last Revissions } & : & \text { 17 Desember 2021 } \\ \text { | Accepted } & : & \text { 20 Desember 2021 } \\ \text { | Copyedits Approved } & : & \text { 21 Desember 2021 }\end{array}$

\begin{abstract}
Credit activities in the banking sector, especially People's Credit Banks during the COVID-19 pandemic are allegedly experiencing a level of sluggishness and indications of the emergence of credit problems, especially in legal certainty for parties who bind themselves to credit so as to give birth to achievements that must be carried out in accordance with the agreed time period. certain. If there are parties who are found to have violated their achievements or do things that should not have been done outside the agreement, then the violators are declared to have committed wan achievements. The purpose of this study is to find out what settlements can be made if the debtor breaks his promise (wan achievement), and to analyze the obstacles in credit settlement at PT BPR Insumo Sumberarto Kediri. The research method used is descriptive analytical research method with an empirical juridical approach. The result of this research is that the procedure for granting credit at PT BPR Insumo Sumberarto Kediri consists of four stages, namely the credit application stage, the credit analysis stage, the credit decision stage and the credit disbursement stage. Takeover of collateral as a credit settlement process if the debtor breaks his promise (wan achievement). Obstacles in credit settlement at PT BPR Insumo Sumberarto Kediri are normative barriers (related to Law Number 8 of 1999 concerning Consumer Protection), internal barriers (poor system performance from banking institutions) and external obstacles (arising from the debtor himself).
\end{abstract}

Keywords: Wan Achievement; Credits; Agreement; Banking. 


\section{A. PENDAHULUAN}

Periode awal tahun 2020 seluruh dunia sedang dilanda wabah yang mengerikan dan membuat seluruh sendi lapisan masyarakat dunia menjadi serba ketakutan dan diselimuti kekhawatiran yang begitu hebat dengan adanya bencana dunia yang disebut corona virus disesase 19. Indonesia merupakan salah satu Negara yang berdampak sangat buruk dalam urusan penyebaran covid 19 ini karena efek yang ditimbulkan tidak hanya pada masalah kesehatan namun juga menyebabkan lumpuhnya sektor-sektor riil ekonomi, yang juga mengakibatkan meningkatnya masalah-masalah dalam aspek hukum dan kemsyarakatan. Keputusan Presiden Republik Indonesia Nomor 12 Tahun 2020 menetapkan penyebaran sebuah virus corona disease 2019 menjadi Bencana Nasional Non Alam. Covid- 19 menimbulkan banyak kebijakan baru dari pemerintah terkait pembatasan kegiatan masyarakat seperti lockdown, social distancing, physical distancing, work from home hingga pembatasan-pembatasan kegiatan masyarakat. ${ }^{1}$

Dampak adanya covid 19 ini salah satunya menyebabkan melemahnya perekonomian Indonesia, akibat pembatasan aktivitas pada ruang gerak bisnis yang mengindikasikan banyaknya pelaksanaan hak dan kewajiban dalam kesepakatan kontrak bisnis terhambat atau bahkan tidak berjalan sesuai dengan rencana, sehingga menimbulkan masalah-masalah yang harus dicari solusinya. ${ }^{2}$ Apabila suatu kesepakatan telah memenuhi syarat sahnya perjanjian sesuai pasal 1320 KUH Perdata, maka berdasarkan pasal 1338 KUH Perdata kesepakatan tersebut berlaku sebagai UndangUndang bagi para pihak yang membuatnya. ${ }^{3}$ Namun, seiring dengan keadaan pandemi ini, terdapat pula keadaan dimana kewajiban atau pretasi tidak terpenuhi yang disebut dengan ingkar janji atau wanprestasi. Dampak hukum dari wanprestasi dapat menyebabkan suatu kontrak dapat dibatalkan atau batal demi hukum.

Sektor finansial salah satunya yaitu perbankan yang mengacu pada kontrak kredit juga menjalankan kegiatan usaha dengan berbagai kesepakatan dan perjanjian kredit. Munculnya Pandemi covid 19 ini juga membawa dampak terhadap kebijakan yang harus dipenuhi oleh debitur untuk membayar utang terhadap kreditur dengan jangka waktu yang telah ditentukan dan disepakati sesuai kontrak kredit tersebut. Wanprestasi tersebut muncul akibat dari ketidakmampuan debitur untuk memenuhi prestasu kepada kreditur. Dalam transaksi bisnis kejadian wanprestasi yang berdampak luas terhadap rencana bisnis sehingga merugikan aspek finansial maupun non finansial seperti nama baik perusahaan dan kepercayaan masyarakat terhadap bisnis yang dijalankan. ${ }^{4}$ Akibat hukum

\footnotetext{
${ }^{1}$ Ida Bagus Gede Manu Widnyana Pemaron and Ida Bagus Putra Atmadja, "Penyelesaian Wanprestasi Dalam Perjanjian Kredit Dengan Jaminan Fidusia Pada Pt Bank Perkreditan Rakyat Kita Di Badung," Kertha Semaya : Journal Ilmu Hukum 7, no. 7 (2019), https://doi.org/10.24843/km.2019.v07.i07. Hlm14.

${ }^{2}$ Ibid.

3 Anak Agung Sri Indrawati Shinta Vinayanti Bumi, "Syarat Subjektif Sahnya Perjanjian Menurut Kitab Undang-Undang Hukum Perdata (Kuh Perdata) Dikaitkan Dengan Perjanjian e-Commerce," Hukum Bisnis Fakultas Hukum Universitas Udayana, 2017.

${ }^{4}$ Frengky Baneftar, "Wanprestasi Dalam Perjanjian Kredit Perbankan Dengan Jaminan Sertifikat Tanah Ditinjau Dari Undang-Undang Nomor 4 Tahun 1996: Studi Pada Bank Papua Cabang Biak," JIHK 5, no. 1 (2020), https://doi.org/10.46924/jihk.v5i1.25.
} 
dari wanprestasi adalah pihak yang tidak dapat melaksanakan perjanjian harus mampu memenuhi tanggungjawabnya untuk mengganti kerugian objek yang telah disepakati dari awal. Akan tetapi adanya upaya renegosiasi dapat dilaksanakan dengan tujuan membatalkan atau mengubah isi kontrak yang disepakati sebelumnya dan tentunya diharapkan adanya itikad baik. ${ }^{5}$

Berbicara mengenai perkreditan atau permodalan, tentunya tidak terlepas dari lembaga keuangan, baik bank maupun lembaga keuangan bukan bank sebagai penghimpun dan penyalur dana masyarakat. Bank sebagai salah satu lembaga keuangan, pada saat ini harus lebih meningkatkan fungsi dan peranannya agar semakin mampu berperan dalam menampung dan menyalurkan aspirasi dan minat masyarakat untuk berperan aktif dalam pembangunan. ${ }^{6}$ Menurut Undang-undang Nomor 10 Tahun 1998 tentang perubahan atas Undang-undang Nomor 7 Tahun 1992 tentang perbankan, pada pasal 1 angka 2 disebutkan : "Bank adalah badan usaha yang menghimpun dana dari masyarakat dalam bentuk kredit dan atau bentuk-bentuk lainnya dalam rangka meningkatkan taraf hidup rakyat banyak. ${ }^{7}$

Sebagaimana Bank Umum, Bank Perkreditan Rakyat sebagai salah satu lembaga keuangan mempunyai berbagai macam kegiatan usaha, termasuk di dalamnya dalam kegiatan usaha dalam bidang pemberian kredit kepada masyarakat, sebagaimana diatur dalam pasal 13 huruf b Undang-undang Nomor 7 Tahun 1992 Jo Undang-undang Nomor 10 Tahun 1998 yang menyebutkan bahwa: "Usaha Bank Perkreditan Rakyat meliputi pemberian kredit." ${ }^{\prime 8}$ Sedangkan pengertian kredit terdapat pada pasal 1 angka 11 Undangundang Nomor 10 Tahun 1992 tentang Perbankan yang menyebutkan sebagai berikut: "Kredit adalah penyediaan uang atau tagihan yang dapat dipersamakan dengan itu, berdasarkan persetujuan atau kesepakatan pinjam-meminjam antar Bank dengan pihak lain yang mewajibkan pihak peminjam untuk melunasi utangnya setelah jangka waktu tertentu dengan pemberian bunga." Bank dalam memberikan bantuan kredit akan memperhatikan kemampuan serta kesanggupan nasabah debitur untuk melunasi utangnya sebagaimana pasal 8 Undang-undang Nomor 10 Tahun 1998 yang menyebutkan: "Dalam memberikan kredit atau pembiayaan berdasarkan Prinsip Syariah, Bank Umum wajib mempunyai keyakinan berdasarkan analisis yang mendalam atau itikad baik dan kemampuan serta kesanggupan Nasabah Debitur untuk melunasi utangnya atau mengembalikan pembiayaan yang dimaksud sesuai dengan yang diperjanjikan."10

\footnotetext{
${ }^{5}$ I B Eka Karanantara, I Nyoman Putu Budiartha, and Ni Made Puspasutari Ujianti, "Wanprestasi Yang Dilakukan Oleh Pihak Debitur Pelaksanaan Perjanjian Kredit Pada Koperasi Dana Rahayu," Jurnal Analogi Hukum 2, no. 2 (2020), https://doi.org/10.22225/ah.2.2.1914.160-164.

${ }^{6}$ Wahyunindyawati Wahyunindyawati and Dyana Sari, "Bank Dan Lembaga Keuangan Lain (Bank and Other Financial Institutions)," SSRN Electronic Journal, 2018, https://doi.org/10.2139/ssrn.3089260.

${ }^{7}$ OJK, Buku Saku Otoritas Jasa Keuangan, Otoritas Jasa Keuangan, 2015. Hlm. 33-40.

${ }^{8}$ Andrew Shandy Utama, "Perkembangan Perbankan Syariah Di Indonesia," UNES Law Review 2, no. 3 (2020), https://doi.org/10.31933/unesrev.v2i3.121.

9 Pemerintah Indonesia, "Undang-Undang Republik Indonesia Nomor 10 Tahun 1998," Lembaran Negara Republik Indonesia, 1998. Hlm 67-69

${ }^{10}$ Ibid.
} 
Walaupun ketentuan pada pasal 8 Undang-undang Nomor 10 Tahun 1998 menyebutkan tentang prinsip pemberian kredit oleh Bank Umum, namun ketentuan pada pasal 8 tersebut juga berlaku bagi Bank Perkreditan Rakyat, sebagaimana telah diatur berdasarkan pasal 15 Undang-undang Nomor 7 Tahun 1992 jo Undang-undang Nomor 10 Tahun 1998. ${ }^{11}$ Dalam prakteknya, Bank sebagai kreditur tidak mau memberikan kredit tanpa adanya jaminan dari nasabah debitur. Hal ini dilakukan untuk menekan resiko mengingat bahwa dalam hubungan kredit ini, pihak pemberi kredit memberikan pinjaman kepada penerima kredit dengan harapan pinjaman itu dapat dipergunakan sebaik-baiknya untuk kemajuan usaha debitur dan pada saat yang ditentukan pinjaman itu harus dikembalikan kepada kreditur. ${ }^{12}$ Oleh karena itu, sebelum memberikan kredit, bank harus melakukan penilaian terhadap watak, kemampuan modal, agunan dan prospek usaha dan nasabah debitur demi keamanan modal dan kepastian hukum bagi pemberi modal (Bank). Perbankan dalam memberikan fasilitas kredit kepada nasabahnya atau masayarakat perlu memperhatikan 5 C yakni Character, Capacity, Capital, Collateral, and Condition Of Economic. ${ }^{13} \mathrm{Hal}$ ini dilakukan oleh pihak perbankan agar dalam proses penyaluran kredit tidak terjadi masalah kredit yang macet, sehingga perlu kehati-hatian pihak penyedia jasa keuagan khususnya perbankan.

PT BPR Insumo Sumberarto Kediri dalam pelaksanaan kegiatan operasionalnya juga terdampak akibat adanya covid 19 ini. Salah satu masalah yang sedang dialami adalah adanya resiko peningkatan jumlah wanprestasi di perusahaan, yaitu kondisi dimana debitur mengalami kesulitan dalam membayarkan pinjamannya. Keadaan dimana dalam suatu perjanjian tidak ditetapkan batas waktu untuk melaksanakan prestasi, maka kreditur harus lebih dahulu menagih pelaksanaan prestasi tersebut. Kreditur harus memberikan peringatan atau teguran kepada debitur agar yang bersangkutan melaksanakan prestasi tersebut. Bentuk teguran ini disebut somasi. ${ }^{14}$ Sebagai pihak yang menghadapi masalah, bank memiliki kebebasan untuk menentukan lembaga mana yang akan dipilih untuk penyelesaian wanprestasi dengan nasabahnya. ${ }^{15}$ Mekanisme penyelesaian kasus wanprestasi terdapat 2 (dua) macam yaitu melalui jalur litigasi dan nonlitigasi. Dalam menangani wanprestasi, pimpinan bank harus tetap berpegang pada pedoman pokok penanganan kredit bermasalah, yaitu usaha penyelamatan kredit secara maksimal. Upaya penyelamatan kredit tersebut dapat dilakukan dengan restrukturisasi kredit. Restrukturisasi kredit dapat melalui penjadwalan kembali, persyaratan kembali, dan penataan kembali. Adapun tujuan dari penelitian ini adalah untuk mengetahui dan

\footnotetext{
${ }^{11}$ Ifa Latifa Fitriani, "Jaminan Dan Agunan Dalam Pembiayaan Bank Syariah Dan Kredit Bank Konvensional," Jurnal Hukum \& Pembangunan 47, no. 1 (2017), https://doi.org/10.21143/jhp.vol47.no1.138.

${ }^{12}$ Fitri Ayu Ranti and Hudi Asrori S, "Penyelesaian Wanprestasi Dalam Perjanjian Kredit Di Bank Bri Kcp Jombang Kota,” Jurnal Privat Law 7, no. 1 (2019), https://doi.org/10.20961/privat.v7i1.30144.

${ }^{13}$ OJK, Buku Saku Otoritas Jasa Keuangan.

${ }^{14}$ Putra PM Siregar and Ajeng Hanifa Zahra, "Bencana Nasional Penyebaran COVID-19 Sebagai Alasan Force Majeure, Apakah Bisa?,” Direktorat Jenderal Kekayaan Negara Kementerian Keuangan, 2020.

15 Meike Binsneyder and Abraham Ferry Rosando, "Akibat Hukum Pengalihan Hak Tanggungan Tanpa Sepengetahuan Kreditur Dalam Tinjauan Asas Keseimbangan Dan Itikad Baik Dalam Putusan Pengadilan," Jurnal Hukum Bisnis Bonum Commune 3, no. 1 (2020), https://doi.org/10.30996/jhbbc.v3i1.3052.
} 
menganalisis prosedur pengajuan kredit di PT BPR Insumo Sumberarto Kediri. ${ }^{16}$ Untuk mengetahui dan menganalisis penyelesaian yang dapat dilakukan oleh PT BPR Insumo Sumberarto,apabila debitur ingkar janji (wan prestasi). Untuk mengetahui dan menganalisis hambatan-hambatan dalam penyelesaian kredit di PT BPR Insumo Sumberarto Kediri.

\section{B. METODE PENELITIAN}

Metode yang peneliti pakai dalam penelitian ini adalah metode penelitian hukum empiris dengan menggunakan fakta-fakta empiris yang diambil dari perilaku manusia, baik perilaku verbal yang didapat dari wawancara maupun perilaku nyata yang dilakukan melalui pengamatan langsung. ${ }^{17}$ Lokasi penelitian dalam penelitian penelitian ini yaitu di PT BPR Insumo Sumberarto Kediri jalan Urip Sumoharjo No. 106 Kediri. Data-data yang digunakan dalam penelitian ini antara lain data primer (secara langsung dari lapangan berdasarkan dari responden dan narasumber) dan data sekunder (mempelajari dan mengumpulkan data yang berhubungan dengan objek penelitian) yaitu 1) bahan hukum primer (KUHP, UU No 10 Tahun 1998 tentang Perubahan Atas UU No 7 Tahun 1992 tentang Perbankan dan UU No 8 Tahun 1999 tentang Perlindungan Konsumen), 2) bahan hukum sekunder (kepustakaan), dan 3) bahan hukum tersier (petunjuk maupun penjelasan terhadap hukum primer dan sekunder). Untuk mengumpulkan data tersebut digunakan tehnik interview dan observasi. Teknik pengolahan dan analisa data menggunakan metode kualitatif yaitu data primer dan data sekunder yang telah terkumpul disusun kembali secara urut dan teratur untuk kemudian dianalisis secara sistematis agar mencapai kejelasan masalah yang dicapai. ${ }^{18}$ Data yang diperoleh secara rinci dan jelas kemudian dianalisis dengan menggunakan teknik deskriptif analisis.

\section{HASIL DAN PEMBAHASAN}

\section{Prosedur Pengajuan Kredit di PT. BPR Insumo Sumberarto Kediri}

Pelaksanaan pemberian kredit yang dilakukan oleh PT. BPR Insumo Sumberarto Kediri melalui Proses pengajuan kredit meliputi :

a. Permohonan kredit.

Untuk mendapatkan kredit terlebih dahulu calon nasabah diharuskan mengajukan permohonan kredit. ${ }^{19}$ Dalam mengajukan permohonan kredit, biasanya calon debitur menyampaikan dokumen-dokumen (surat permohonan, KTP, KK, slip gaji, SK Pengangkatan Kerja, NPWP, dll). Suatu permohonan kredit dituntut adanya kejelasan dan kelengkapan dalam berkas permohonan kreditnya.

\footnotetext{
${ }^{16}$ Lina Maya Sari, Lukuk Musfiroh, and Ambarwati, "Restrukturisasi Kredit Bank Daerah X Pada Masa Pademi Covid-19," Jurnal Mutiara Madani 08, no. 1 (2020).

${ }^{17}$ Dr. M.A. Lexy J. Moleong, "Metodologi Penelitian Kualitatif (Edisi Revisi)," PT. Remaja Rosda Karya, 2019, https://doi.org/10.1016/j.carbpol.2013.02.055.

${ }^{18}$ Sugiyono, Metode Peneiltian Kuantitatif, Kualitatif Dan R\&D, Alfabeta Bandung, 2018.

${ }^{19}$ I Made Adi Guntara and Ni Made Ari Yuliartini Griadhi, "Penerapan Prinsip 5C Sebagai Upaya Perlindungan Terhadap Bank Dalam Menyalurkan Kredit,” Kertha Semaya : Journal Ilmu Hukum Vol 7 No 8 (2019).
} 
b. Analisa kredit.

Analisis kredit yang dilakukan petugas bank meliputi analisis $5 \mathrm{C}$ yaitu analisis watak, kemampuan, modal, kondisi atau prospek usaha dan jaminan merupakan tahap yang penting dalam penentuan keputusan yang akan diambil oleh bank terhadap permohonan kredit. ${ }^{20}$ Tahap ini dilakukan setelah permohonan kredit yang membutuhkan data-data yang dapat menunjang kegiatan tersebut. Dalam melakukan analisis kredit menggunakan pedoman atau dasar penilaian yang ditentukan bank

c. Keputusan kredit.

Dalam tahap keputusan kredit, bank mengambil keputusan atas permohonan kredit apakah disetujui atau ditolak. Adapun yang menjadi bahan pertimbangan dalam pengambilan keputusan tersebut adalah hasil analisis kredit. Bank dalam memberikan putusan persetujuan kredit mencantumkan ketentuan-ketentuan kredit. $^{21}$

d. Pencairan kredit.

Pencairan kredit dapat dilakukan setelah instruksi pencairan kredit ditandatangani oleh pejabat yang berwenang. Adapun syarat untuk menerbitkan intruksi pencairan kredit adalah adanya surat perjanjian yang sah, semua dokumen yang ditetapkan dalam putusan kredit telah lengkap dan sah serta telah memberikan perlindungan bagi bank, serta semua biaya yang berkaitan dengan pemberian kredit telah dilunasi nasabah. Kredit dapat dibayarkan apabila semua persyaratan sudah dipenuhi. Dalam pemenuhan persyaratan tersebut, terdapat dokumentasi yang dilakukan bank demi keamanan kredit. ${ }^{22}$

\section{Upaya Penyelesaian yang Dapat Dilakukan oleh PT. BPR Insumo Sumberarto Kediri Apabila Debitur Ingkar Janji (Wan Prestasi)}

Penyelesaian yang dapat dilakukan oleh PT. BPR Insumo Sumberarto, apabila debitur ingkar janji (wan prestasi) adalah pengambilalihan agunan sebagai proses penyelesaian kredit. Debitur menyerahkan agunan untuk dijual dan hasilnya digunakan untuk melunasi jumlah kewajiban kredit dan sisanya dikembalikan kepada Debitur dan bilamana kurang debitur wajib menambahkan kekurangannya karena perjanjian kredit belum berakhir.

Kredit bermasalah pada mulanya diawali terjadinya wanprestasi (ingkar janji), dimana debitur tidak mau atau tidak mampu memenuhi janji yang telah dibuatnya dalam Perjanjian Kredit. $^{23}$ Wanprestasi dianggap sebagai suatu kegagalan untuk

\footnotetext{
${ }^{20}$ Fredy Jehantana, "Pengaruh Analisis 5c Terhadap Kebijakan Kredit Pada KPN Werdhi Yasa," Jurnal Akuntansi Profesi 10, no. 1 (2019), https://doi.org/10.23887/jap.v10i1.21037.

${ }^{21}$ Fitriani, "Jaminan Dan Agunan Dalam Pembiayaan Bank Syariah Dan Kredit Bank Konvensional."

${ }^{22}$ Baneftar, "Wanprestasi Dalam Perjanjian Kredit Perbankan Dengan Jaminan Sertifikat Tanah Ditinjau Dari Undang-Undang Nomor 4 Tahun 1996: Studi Pada Bank Papua Cabang Biak."

${ }^{23}$ Sultan Saiful, Hukum Bisnis , Business Law, Create Spaces.Com , 2018.
} 
melaksanakan janji yang telah disepakati disebabkan debitur tidak melaksanakan kewajiban tanpa alasan yang dapat diterima oleh hukum. Atau dapat juga dikatakan debitur sama sekali tidak memenuhi prestasi, tidak tunai memenuhi prestasi, terlambat memenuhi prestasi, atau keliru memenuhi prestasi. ${ }^{24}$

Pemerintah dalam rangka mengatasi kesulitan pelaksanaan perjanjian telah melakukan penanggulangan bencana dengan mengeluarkan peraturan terbaru yakni Peraturan Otoritas Jasa Keuangan Nomor 11/POJK.03/2020 tentang Stimulus Perekonomian Nasional Sebagai Kebijakan Counter cyclical Dampak Penyebaran Corona Virus Disease 2019 saat Pandemi COVID-19 berlangsung Peraturan ini dibuat untuk mengantisipasi melonjaknya jumlah kredit bermasalah selama pandemi berlangsung. ${ }^{25}$ Dengan diberlakukannya peraturan tersebut, PT. BPR Insumo Sumberarto Kediri menerapkan peraturan tersebut dan membuat pedoman dan kebijakan dampak penyebaran COVID-19.

Peraturan Otoritas Jasa Keuangan Nomor 11/POJK.03/2020 tentang Stimulus Perekonomian Nasional Sebagai Kebijakan Countercyclical Dampak Penyebaran Corona Virus Disease 2019 menjelaskan bahwa penetapan kualitas asset kredit pada BPR bagi debitur yang terkena dampak penyebaran coronavirus disease 2019 (COVID-19) termasuk debitur usaha mikro, kecil, dan menengah adalah dengan plafon paling banyak Rp10.000.000.000,00 (sepuluh miliar rupiah) yang dilihat pada ketepatan pembayaran pokok dan/atau bunga atau margin/bagi hasil/ujrah. ${ }^{26}$ Menurut penjelasan Pasal 2 ayat (1) Peraturan Otoritas Jasa Keuangan Nomor 11/POJK.03/2020 tentang Stimulus Perekonomian Nasional sebagai kebijakan Counter cyclical dampak penyebaran corona virus disease 2019, debitur yang terkena dampak penyebaran COVID-19 termasuk debitur usaha mikro, kecil, dan menengah adalah "Debitur yang mengalami kesulitan untuk memenuhi kewajiban pada Bank karena debitur atau usaha debitur terdampak dari penyebaran coronavirus disease 2019 (COVID-19) baik secara langsung ataupun tidak langsung pada sektor ekonomi antara lain pariwisata, transportasi, perhotelan, perdagangan, pengolahan, pertanian, dan pertambangan."27

Debitur PT. BPR Insumo Sumberarto Kediri tidak jarang melakukan wanprestasi perjanjian kredit. Debitur pada PT. BPR Insumo Sumberarto Kediri dapat dikatakan wanprestasi perjanjian kredit apabila debitur tersebut melakukan satu atau lebih kejadian sebagaimana telah diatur dalam Pasal 14 Perjanjian Kredit. Debitur yang melakukan wanprestasi saat pandemi COVID-19 berlangsung tidak ada yang

\footnotetext{
24 Karanantara, Budiartha, and Ujianti, "Wanprestasi Yang Dilakukan Oleh Pihak Debitur Pelaksanaan Perjanjian Kredit Pada Koperasi Dana Rahayu."

${ }^{25}$ Siregar and Zahra, "Bencana Nasional Penyebaran COVID-19 Sebagai Alasan Force Majeure, Apakah Bisa?"

${ }^{26}$ Dhevi Nayasari Satradinata and Bambang Eko Muljono, "Analisis Hukum Relaksasi Kreadit Saat Pandemi Corona Dengan Kelonggaran Kredit Berdasarkan Peraturan Otoritas Jasa Keuangan Nomor 11/POJK.03/2020," Jurnal Sains Sosio Humaniora 4, no. 2 (2020), https://doi.org/10.22437/jssh.v4i2.11009.

${ }^{27}$ Abdul Kholiq and Rizqi Rahmawati, "Dampak Implementasi Restrukturisasi Pembiayaan Terhadap Likuiditas Bank Syariah Pada Situasi Pandemi Covid-19," El-Barka: Journal of Islamic Economics and Business 3, no. 2 (2020), https://doi.org/10.21154/elbarka.v3i2.2472.
} 
menyelesaikan perselisihan melalui pengadilan. Debitur yang wanprestasi akan diberikan surat teguran oleh kreditur setelah melewati batas pembayaran. Debitur PT. BPR Insumo Sumberarto Kediri yang telah ditetapkan melakukan wanprestasi dapat diselesaikan dengan 2 cara yaitu penyelamatan dan penyelesaian kredit. Penyelamatan dan penyelesaian kredit akan dilakukan pihak BPR apabila terjadi kredit bermasalah. Penyelamatan adalah suatu langkah penyelesaian kredit bermasalah melalui perundingan kembali antara kreditur dan debitur dengan memperingan syarat-syarat pengembalian kredit tersebut diharapkan debitur dapat memiliki kemampuan kembali untuk menyelesaikan kredit itu. Pengertian penyelesaian kredit adalah langkah penyelesaian kredit bermasalah melalui lembaga hukum seperti Pengadilan atau Direktorat Jendral Piutang dan Lelang Negara atau badan lainnya dikarenakan langkah penyelamatan sudah tidak dimungkinkan kembali. ${ }^{28}$

Tujuan penyelesaian kredit melalui lembaga hukum ini adalah untuk menjual atau mengeksekusi benda jaminan Upaya yang dapat dilakukan PT. BPR Insumo Sumberarto Kediri terhadap debitur yang telah melakukan wanprestasi perjanjian kredit pada bulan Maret 2020 sampai Agustus 2021 adalah Restrukturisasi Kredit. Restrukturisasi kredit bermasalah adalah suatu upaya penyelamatan kredit perbankan dan juga upaya menyehatkan kembali keuangan nasabah peminjam termasuk penyehatan asset bank sehingga dengan lancarnya kembali pembayaran kredit oleh nasabah peminjam maka akan tercipta suatu penyelamatan dan penyehatan di kedua sisi yaitu bank selaku kreditur dari segi penyelamatan kredit dan penyehatan asset bank dan dari sisi nasabah peminjam penyehatan kembali kelangsungan usahanya sehingga dapat berjalan sebagaimana mestinya. ${ }^{29}$

\section{Hambatan-hambatan dalam Penyelesaian Kredit di PT. BPR Insumo Sumberarto Kediri}

a. Hambatan Normatif

Timbul dari peraturan mengenai lembaga perbankan dan perjanjian kredit yang berlaku. Peraturan mengenai lembaga perbankan tersebut dikaitkan dengan Undang-Undang Nomor 8 tahun 1999 tentang Perlindungan Konsumen yang berlaku apabila lembaga perbankan melanggar kewajiban dan larangan peraturan perundang-undangan secara perdata yang dapat merugikan konsumen. ${ }^{30}$

b. Hambatan internal

Timbul dari permasalahan dalam lembaga perbankan meliputi sistem kinerja yang kurang bagus dari lembaga perbankan, namun para karyawan PT. BPR Insumo

\footnotetext{
${ }^{28}$ Pemaron and Atmadja, "Penyelesaian Wanprestasi Dalam Perjanjian Kredit Dengan Jaminan Fidusia Pada PT Bank Perkreditan Rakyat Kita Di Badung."

${ }^{29}$ Sari, Musfiroh, and Ambarwati, "Restrukturisasi Kredit Bank Daerah X Pada Masa Pademi Covid-19."

${ }^{30}$ Wahyu Simon Tampubolon, "Upaya Perlindungan Hukum Bagi Konsumen Ditinjau Dari Undang Undang Perlindungan Konsumen,” Jurnal Ilmiah 04, no. 01 (2016).
} 
Sumberarto Kediri bekerja dengan baik dan bertanggung jawab atas pekerjaan masing-masing sehingga hambatan internal ini dapat terhindarkan.

c. Hambatan Eksternal

Timbul dari debitur itu sendiri, yaitu adanya perbuatan melawan hukum terhadap perjanjian kredit yang telah disepakati oleh pihak PT. BPR Insumo Sumberarto Kediri dengan debitur. Hambatan-hambatan eksternal tersebut meliputi

1. Debitur sudah tidak ada karena meninggal / tidak jelas alamatnya (minggat) dan tidak ada ahli warisnya

2. Debitur mempunyai kewajiban di berbagai lembaga keuangan;

3. Debitur beritikad tidak baik dengan sengaja tidak memenuhi kewajibannya;

4. Usaha milik debitur mengalami penurunan penghasilan atau bahkan usahanya gagal atau rugi

5. Jaminan menyusut, nilainya lebih kecil dari nilai kewajiban debitur; dan

6. debitur lalai, kurang memahami, dan/atau tidak memperhatikan isi dari perjanjian kredit.

7. Kemampuan debitur rendah untuk pemenuhan kewajiban karena banyaknya kebutuhan dari pihak debitur untuk kepentingan yang lain.

8. Perjanjian kredit tidak disertai dengan perjanjian jaminan, sehingga kesulitan dalam penyelesaian kewajiban debitur

\section{KESIMPULAN}

Saat terjadinya peristiwa bencana dunia covid 19 mempengaruhi kinerja perbankan khususnya dalam hal penyaluran kredit, yang berdampak pada prosedur pengajuan kredit hingga masalah wanprestasi yang dilakukan oleh debitur khususnya problematika yang terjadi di PT. Insumo Sumberarto Kediri. Hasil penelitian menjukkan bahwa : 1) Prosedur pengajuan kredit di PT BPR Insumo Sumberarto Kediri ada empat tahapan yaitu tahap permohonan kredit, tahap analisis kredit, tahap keputusan kredit dan tahap pencairan kredit. 2) Masalah penyelesaian yang dapat dilakukan oleh PT BPR Insumo Sumberarto, apabila debitur ingkar janji (wan prestasi) adalah pengambilalihan agunan sebagai proses penyelesaian kredit. Debitur menyerahkan agunan untuk dijual dan hasilnya digunakan untuk melunasi jumlah kewajiban kredit dan sisanya dikembalikan kepada Debitur dan bilamana kurang debitur wajib menambahkan kekurangannya karena perjanjian kredit belum berakhir. 3) Hambatan-hambatan dalam penyelesaian kredit di PT BPR Insumo Sumberarto Kediri, melalui hambatan normatif terkait Undang-Undang Nomor 8 tahun 1999 tentang Perlindungan Konsumen dan hambatan internal mengenai sistem kinerja yang kurang bagus dari lembaga perbankan, Hambatan eksternal (hambatan timbul dari debitur). 


\section{DAFTAR PUSTAKA}

\section{Buku :}

Lexy J. Moleong, Dr. M.A. "Metodologi Penelitian Kualitatif (Edisi Revisi).” PT. Remaja Rosda Karya, 2019. https://doi.org/10.1016/j.carbpol.2013.02.055.

OJK. Buku Saku Otoritas Jasa Keuangan. Otoritas Jasa Keuangan, 2015.

Saiful, Sultan. Hukum Bisnis , Business Law. CreateSpaces. Com, 2018.

Sugiyono. Metode Peneiltian Kuantitatif, Kualitatif Dan R\&D. Alfabeta Bandung, 2018.

\section{Jurnal :}

Fitri Ayu Ranti, and, Hudi Asrori S. "Penyelesaian Wanprestasi Dalam Perjanjian Kredit Di Bank BRI KCP Jombang Kota." Jurnal Privat Law 7, no. 1 (2019). https://doi.org/10.20961/privat.v7i1.30144.

Baneftar, Frengky. "Wanprestasi Dalam Perjanjian Kredit Perbankan Dengan Jaminan Sertifikat Tanah Ditinjau Dari Undang-Undang Nomor 4 Tahun 1996: Studi Pada Bank Papua Cabang Biak.” JIHK 5, no. 1 (2020). https://doi.org/10.46924/jihk.v5i1.25.

Binsneyder, Meike, and Abraham Ferry Rosando. "Akibat Hukum Pengalihan Hak Tanggungan Tanpa Sepengetahuan Kreditur Dalam Tinjauan Asas Keseimbangan Dan Itikad Baik Dalam Putusan Pengadilan.” Jurnal Hukum Bisnis Bonum Commune 3, no. 1 (2020). https://doi.org/10.30996/jhbbc.v3i1.3052.

Fitriani, Ifa Latifa. "Jaminan Dan Agunan Dalam Pembiayaan Bank Syariah Dan Kredit Bank Konvensional." Jurnal Hukum \& Pembangunan 47, no. 1 (2017). https://doi.org/10.21143/jhp.vol47.no1.138.

Guntara, I Made Adi, and Ni Made Ari Yuliartini Griadhi. "Penerapan Prinsip 5C Sebagai Upaya Perlindungan Terhadap Bank Dalam Menyalurkan Kredit.” Kertha Semaya: Journal Ilmu Hukum Vol 7 No 8 (2019).

Jehantana, Fredy. "Pengaruh Analisis 5c Terhadap Kebijakan Kredit Pada KPN Werdhi Yasa." Jurnal Akuntansi Profesi 10, no. 1 (2019). https://doi.org/10.23887/jap.v10i1.21037.

Karanantara, I B Eka, I Nyoman Putu Budiartha, and Ni Made Puspasutari Ujianti. "Wanprestasi Yang Dilakukan Oleh Pihak Debitur Pelaksanaan Perjanjian Kredit Pada Koperasi Dana Rahayu." Jurnal Analogi Hukum 2, no. 2 (2020). https://doi.org/10.22225/ah.2.2.1914.160-164.

Kholiq, Abdul, and Rizqi Rahmawati. "Dampak Implementasi Restrukturisasi Pembiayaan Terhadap Likuiditas Bank Syariah Pada Situasi Pandemi Covid-19.” El-Barka: Journal of Islamic Economics and Business 3, no. 2 (2020). https://doi.org/10.21154/elbarka.v3i2.2472.

Pemaron, Ida Bagus Gede Manu Widnyana, and Ida Bagus Putra Atmadja. "Penyelesaian Wanprestasi Dalam Perjanjian Kredit Dengan Jaminan Fidusia Pada PT Bank Perkreditan Rakyat Kita Di Badung.” Kertha Semaya: Journal Ilmu Hukum 7, no. 7 (2019). https://doi.org/10.24843/km.2019.v07.i07.p14. 
Sari, Lina Maya, Lukuk Musfiroh, and Ambarwati. "Restrukturisasi Kredit Bank Daerah X Pada Masa Pademi Covid-19.” Jurnal Mutiara Madani 08, no. 1 (2020).

Satradinata, Dhevi Nayasari, and Bambang Eko Muljono. "Analisis Hukum Relaksasi Kreadit Saat Pandemi Corona Dengan Kelonggaran Kredit Berdasarkan Peraturan Otoritas Jasa Keuangan Nomor 11/POJK.03/2020.” Jurnal Sains Sosio Humaniora 4, no. 2 (2020). https://doi.org/10.22437/jssh.v4i2.11009.

Shandy Utama, Andrew. "Perkembangan Perbankan Syariah Di Indonesia." UNES Law Review 2, no. 3 (2020). https://doi.org/10.31933/unesrev.v2i3.121.

Shinta Vinayanti Bumi, Anak Agung Sri Indrawati. "Syarat Subjektif Sahnya Perjanjian Menurut Kitab Undang-Undang Hukum Perdata (Kuh Perdata) Dikaitkan Dengan Perjanjian e-Commerce.” Hukum Bisnis Fakultas Hukum Universitas Udayana, 2017.

Siregar, Putra PM, and Ajeng Hanifa Zahra. "Bencana Nasional Penyebaran COVID-19 Sebagai Alasan Force Majeure, Apakah Bisa?" Direktorat Jenderal Kekayaan Negara Kementerian Keuangan, 2020.

Wahyu Simon Tampubolon. "Upaya Perlindungan Hukum Bagi Konsumen Ditinjau Dari Undang-Undang Perlindungan Konsumen.” Jurnal Ilmiah 04, no. 01 (2016).

Wahyunindyawati, Wahyunindyawati, and Dyana Sari. "Bank Dan Lembaga Keuangan Lain (Bank and Other Financial Institutions)." SSRN Electronic Journal, 2018. https://doi.org/10.2139/ssrn.3089260.

\section{Peraturan Perundang-undangan :}

Pemerintah Indonesia. "Undang-Undang Republik Indonesia Nomor 10 Tahun 1998." Lembaran Negara Republik Indonesia, 1998. 
AJUDIKASI : Jurnal Ilmu Hukum, Volume 5 Nomor 2, Desember 2021. Hlm. 123-134

P-ISSN 2613-9995 \& E-ISSN 2614-0179 